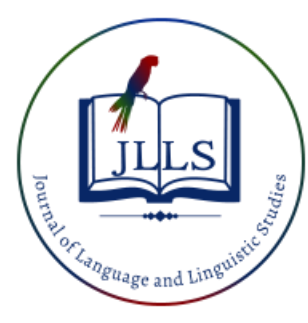

Available online at www.jlls.org

JOURNAL OF LANGUAGE AND LINGUISTIC STUDIES

ISSN: $1305-578 \mathrm{X}$

Journal of Language and Linguistic Studies, 16(3), 1282-1308; 2020

\title{
Evaluation of the English language coursebooks used at the Turkish public elementary schools
}

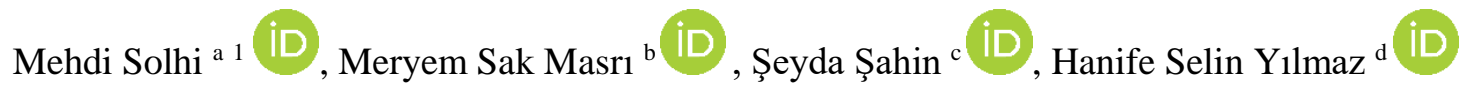

\author{
a Istanbul Medipol University, Istanbul, Turkey \\ Istanbul Medipol University, Istanbul, Turkey \\ c Istanbul Medipol University, Istanbul, Turkey \\ d Istanbul Medipol University, Istanbul, Turkey
}

APA Citation:

Solhi, M., Sak Masrı, M., Şahin, Ş., \& Yılmaz, H. S. (2020). Evaluation of the English language coursebooks used at the Turkish public elementary schools. Journal of Language and Linguistic Studies, 16(3), 1282-1308.

Submission Date:09/0472020

Acceptance Date:25/05/2020

\begin{abstract}
This study sought to evaluate the English language coursebooks used at the Turkish public elementary schools. In so doing, a series of coursebooks used in English courses of the curriculum prepared by the Turkish Ministry of National Education were evaluated, using Tomlinson and Masuhara's (2013) set of coursebook evaluation universal criteria. Results indicated that the layout, listening skill, illustrations in use, and affective engagement are the positive traits of the coursebooks, while the negative features outnumber the positive traits. The evaluation indicated that the Turkish public elementary English coursebooks are void of a number of important aspects of language acquisition, including communication-based activities, continuation of using English outside of the classroom, discovery enhancing input and most importantly extensive exposure to English. The central focus of the coursebooks is on the accuracy and repetition rather than effective outcomes, meaningful communication and long term language acquisition. Most activities in all coursebooks contain practice activities, with no place for productivity and autonomy on the part of the students. Additionally, there is no sufficient personalization and the coursebooks fail to make use of what students bring to classroom. Nor are the learners required to think critically, creatively or analytically in most of the activities. The coursebooks do not encourage learners to continue learning English by themselves, thus lacks encouragement for autonomy as well. The activities are designed to practice language items within the classroom environments. Hence, learning does not go beyond the classroom environment with the help of the coursebooks. Nor do the coursebooks guide or encourage learners to make discoveries by themselves. The bombardment of repetitive practice activities that only assess accuracy does not seem to be able to lead to long-term acquisition of English.
\end{abstract}

(C) 2020 JLLS and the Authors - Published by JLLS.

Keywords: coursebooks; coursebooks evaluation; public schools; English deficit

\footnotetext{
${ }^{1}$ Corresponding author. Tel.: +90-216-681-5100/1717

E-mail address: solhi.mehdi@gmail.com
} 


\section{Introduction}

Materials can refer to any type of instruments which facilitates language learning. Gray (2006) defines materials as anything used in teaching to aid language learners, including coursebooks, practice books, handouts, visual/auditory CDs or cassettes, or newspapers. In total, they refer to anything which informs and present about the language being acquired. In fact, today's materials provide language learners with complete learning packages and they have made the classroom activities more effective than before (Littlejohn, 1998). A dynamic language lesson results from a co-production by the teacher and the learners in interaction with materials (Allwright, 1981). In a similar vein, Crewe (2011) maintains that the teaching-learning experience generally comprises three fundamental entities: students, teacher, and instructional materials.

Coursebooks, as the most commonly used and recognized instructional materials, and teaching tools, possess a facilitating and prime role in foreign language education (Sercu, 2005). They generally offer structured content in a uniform format for ready implementation. As such, they are a primary resource and central element for use in teaching-learning encounters, not only in school settings but frequently also in tertiary-level English contexts. As Haycroft (1998) indicated more than two decades ago, coursebook can give an authority on the teacher to mediate the learning and teaching contents, and it also provides the students with quantifiable record to study and learn. Other strand of qualities attributed to coursebook involves giving a face validity to language learning process (Dubin \& Olshtain 1986), catering a source of ideational scaffolding for learning (Kramsch, 1988), providing details on classroom procedures (Hutchinson \& Torres, 1994), acting as a resource and point of reference (Cunningsworth, 1995), triggering the intercultural competence of the learners (McKay, 2003), constituting the guiding principle of language courses (Davcheva \& Sercu, 2005), possessing a fundamental role in structuring the language learning lesson (Gray, 2006), introducing culture and values (Bahman \& Rahimi, 2010), helping both as a syllabus and as a framework of classroom progress (Tsiplakides, 2011), providing similar content to different classes and making evaluation process easier (Abdelwahab, 2013), and saving and lessening preparation time (Tsiplakides, 2011; Dodgson, 2019).

Notwithstanding the aforementioned traits of materials and coursebooks in language learning, it was not until the 1990s when researchers and educators started to pay more detailed attention on teaching materials and materials evaluation, and they have been the focal point of systematic studies over the last decades. Materials evaluation, as Tomlinson (2013, p. 1) defines, "is a procedure that involves measuring the value (or potential value) of a set of learning materials". He goes on indicating that it encompasses forming judgments about the influence of the materials on the ones who use them, and it tries to measure, say, to what extent they are appealing, interesting, credible, valid, reliable, motivating, adaptable, and how much they are likely to lead to short-term/ long-term learning, what the learner's/teacher's perception on their value is, and whether they can potentially contribute to teacher development. In evaluation of the materials, it is the effects of the materials not the materials themselves that are taken into close scrutiny. Hence, an evaluation takes into account the ones who use the materials, and form judgments on their effectiveness. More than two decades ago, Sheldon (1988) asserted that there is no accurate framework or a system for coursebook assessment, which makes this process essentially subjective. Echoing Sheldon, Tomlinson (2013) also maintains that the nature of materials evaluation is inevitably subjective no matter how accurate, standardized, and criterion referenced an evaluation claims to be. So no two evaluations are likely to be necessarily identical as the requirements, backgrounds and favored styles of the individuals are likely to be different depending on the context they use the materials.

Different from evaluation that focuses on the users of the materials and is subjective in approaching the materials, analysis takes into account the materials themselves, and it strives to make an objective 
judgment of them. So, in analysis of the materials, it is, say, the content, the purpose, tasks, and the instructions in the materials that are taken into account (Tomlinson, 1999). To give an example, an analyst might ask the question 'Does the coursebook provide the transcript of the listening activities?' to indicate whether the printing text of a recording is provided, while an evaluator might ask 'To what extent do the listening activities in the coursebook target the learner involvement?' Notwithstanding that analysis is ideally expected to be objective, analysts are often influenced by their own beliefs (i.e., hidden agenda) and hence their questions tend to be biased accordingly (Tomlinson, 2013). For example, an analyst might ask the question 'Does the coursebook provide a lot of guided speaking activities?' In this example, the analyst's choice of word 'a lot' indicates her/his hidden agenda and leads to the biased analysis of the content of the material.

Tomlinson (2013) categorizes the materials evaluation into three types: pre-use evaluation, whilstuse evaluation, and post-use evaluation. In pre-use evaluation, evaluators aim at making predictions about the potential value of materials for their users. In so doing, an evaluation needs to be accurate, standardized, and criterion referenced with the collaboration of at least two evaluators to make an evaluation more reliable and principled. At the outset, the evaluators need to independently carry out the evaluation and then come to mutual conclusions. Whilst-use evaluation encompasses ascertaining the value of materials when they are being used in teaching practices. In comparison to pre-use evaluation, this type of evaluation tends to be more objective and reliable as it measures the actual use of the materials rather than making predictions on them. However, measuring the long-term effectiveness and durable learning of the materials do not seem to be possible as it only measures the observable performances of the users in teaching practices. Being the most beneficial evaluation type, post-use evaluation is more likely to indicate the actual effectiveness and the outcomes of the materials on the users. In this type of evaluation, both the short-term effects of the materials (e.g., achievability, motivation, instant learning) and their long-term values (e.g., application and durable learning) can be measured. In fact, after post-use evaluation, more trustworthy conclusions on the use, replacement or adaptation of the materials can be reached. However, it is quite difficult to reliably carry out post-use evaluation as it may require large amount of time and expertise (Tomlinson, 2013).

In pre-use evaluation, the usage and preparation of an accurate and standardized checklist of criteria has always been prevalent down the years to facilitate the process of coursebook selection (e.g., Skierso, 1991; McDonough \& Shaw, 1993; Cunningsworth, 1995; Ur, 1996; Brown, 1997; Chambers, 1997; Littlejohn, 1998; Gearing, 1999; Byrd, 2001). Notwithstanding the large body of checklists, no set of criteria is applicable to all situations (Tomlinson, 2013), and the majority of them are reported to be context-bound (Mukundan \& Ahour, 2010). Despite the large number of checklists for the coursebook evaluation, most of them are deficient in having rating and weighting schemes (Şimşek \& Dündar, 2018). Mukundan and Ahour (2010) recommend utilizing a framework that takes more flexible criteria into account rather than generating inflexible checklists that are context-specific.

Calling for the evaluators to develop their own set of universal criteria for materials evaluation, Tomlinson (2013, p. 37) defines universal criteria as the ones that "would apply to any language learning materials anywhere for any learners". Tomlinson and Masuhara's (2013) used set of universal criteria possess fifteen criteria which are deemed to reliably predict the long-term effectiveness of the coursebooks. The following fifteen questions are asked in Tomlinson and Masuhara's (2013) universal criteria for coursebook evaluation:

To what extent is the coursebook likely to

1. provide extensive exposure to English in use?

2. engage the learners affectively?

3. engage the learners cognitively? 
4. provide an achievable challenge?

5. help learners to personalize their learning?

6. help the learners to make discoveries about how English is typically used?

7. provide opportunities to use the target language for communication?

8. help the learners to develop cultural awareness?

9. help the learners to make use of the English environment outside the classroom?

10. cater for the needs of all the learners?

11. provide the flexibility needed for effective localization?

12. help the learners to continue to learn English after the course?

13. help learners to use ELF?

14. help learners to become effective communicators in English?

15. achieve its stated objectives?

English is taught as a foreign language in Turkey and is regarded as a requisite skill to obtain in Turkish educational system. The accelerating spread of English as a global language of communication over the last decades has dramatically influenced the linguistic policies of non-English speaking countries. As a result of globalization and the consequent need for English language, and Turkey's announced intention to adapt its English education to European Union standards, the role of English has grasped a growing importance in the country. After the reform movement in the educational system of Turkey in 1997, the introduction of English language shifted from the secondary school to the primary school. In 2011, the Turkey Ministry of National Education set out to take certain steps to improve language education in Turkey, one of which was to thoroughly revise their approach to language, with an additional plan to recruit 40000 non-Turkish instructors as language assistants in public schools. As a consequence, in 2012 English started to be taught from second grade onwards to the end of the high school, and the number of teaching hours was increased.

However, despite the 1997 and 2011 reforms and introducing the English language at an early age, the reality of the success in achieving the expected proficiency has seemingly fallen short of the expectations. According to the EF EPI (English proficiency index) results, Turkey's proficiency in English language falls short among other non-English speaking countries, and is constantly ranked very low on various global proficiency benchmarks. To give an example, the EPI report released in 2013 ranked Turkey 41st out of 60 countries (Vale et al., 2013). The EPI report in 2014 positioned Turkey 47 th among the world countries, while it was ranked the last among the 24 countries in Europe. Turkey's underperforming has been statistically aggravated as its ranking was 77th out of 88 countries in 2018 and 79th out of 100 countries in 2019. In 2012, the average score of both native Turkish speakers and the ones residing in Turkey in Test of English as a Foreign Language (TOEFL) was 75 over 120, making Turkey's ranking close to Sudan and Ethiopia. All these statistics indicate the grim reality of the English deficit in Turkey in general and Turkish educational system in particular.

In fact, Turkey is reported to be underperforming in English language teaching (ELT), and the English deficit of Turkish students has been a hotly-debated issue over the last years. Despite the endeavors made by the ministry to improve the upshots of the foreign language acquisition in Turkey, as aforementioned, the educational reforms and the endeavors have fell short of the expectations and have been generally deemed to be simply insufficient and not altogether satisfactory. With the premise that the language coursebooks play an eminent role and noteworthy contribution in language learning process, the evaluation of the English coursebooks of the Turkish public elementary schools with a set of universal criteria would shed light on the efficacy of their contents and would pave the way to 
thoroughly understand to what extent they can lead to long-term acquisition of English in public schools. In so doing, inspired by this unsatisfactory fall and linguistic deficiency seen in the EF EPI final report, we set out to examine and evaluate English coursebooks that are published by the Republic of Turkey Ministry of National Education to explore the efficacy of the aforementioned coursebooks at the Turkish public elementary schools, and investigate the potential reasons why Turkey has scored very low in the English language proficiency. It is worth noting that as the nature of this paper is evaluation, the interpretations and scores are based on opinions of the group of four evaluators.

\subsection{Literature review}

A number of studies have explored the attitudes of learners and teachers in respect to the effectiveness of the coursebooks being used at Turkish schools. For instance, Özdemir (2007) investigated the teachers and students perception on the effectiveness of Time for English coursebook used at the fourth grade of public schools in Turkey. Evident satisfaction with the coursebook was reported by both the teacher and the students, with a higher contentedness among the students. The instructions and the songs in the coursebook were reported by the students to be the problematic sections, while the number of the units and vocabulary, the presentation of the linguistic items, and the teacher's book were indicated by the teachers to be the other deficiencies of the coursebook. Arikan (2008) similarly looked at the attitudes of both fourth grade students and teachers in connection with the efficiency of the coursebooks. According to the results, only around 30 percent of the teacher participants expressed their approval with the coursebooks. In contrast, more than 60 percent of the students attributed positive senses to the overall evaluation of the textbook. The organization of the design and layout of the coursebook were reported to be quite satisfactory by half $(\mathrm{N}=352)$ of the student participants. However, only around 33 percent of the teacher participants expressed their contentedness with the alleged feature.

In a recent study, Dülger (2016) also explored 118 Turkish teachers' beliefs on the efficacy of the ELT coursebooks used at public schools. According to the results, the analyzed coursebooks received the mean score below average in the areas, say, listening, speaking, grammar and writing, while the highest mean score was obtained in the syllabus and the curriculum. Reading and vocabulary were reported to be average among some other variables. Echoing Dülger, more than a decade ago Çakıt's (2006) investigation on the teachers and the students' beliefs about the English coursebooks and Kayapınar's (2009) study with Turkish high school teachers ( $N=134)$ also revealed that they both in general possess negative attitudes toward the coursebooks, and they advocated developing coursebooks to fulfill the needs of the Turkish students. In a recent study, Öz (2019) similarly demonstrated moderate satisfaction with the coursebooks, while the both teachers and the students were reported to be quite dissatisfied with the practical sections in the coursebooks. In a nutshell, the strand of research conducted in Turkey on the effectiveness of the coursebooks used at public schools indicates that both the teachers and students' perceptions on the coursebooks are not entirely satisfactory.

Apparently, a limited number of studies have measured and evaluated the effectiveness of the ELT coursebooks using Tomlinson and Masuhara's (2013) set of universal criteria. On the other hand, notwithstanding the large number of literature on the evaluation of the English language learning coursebooks used at school in Turkey, the majority of the evaluation studies have only considered the perception of the students and the teachers (e.g., Çakıt, 2006; Aytuğ, 2007; Arıkan, 2008; Kayapınar, 2009; Dülger, 2016; Akkaya, 2019; Öz, 2019), and hence seemingly no study has been conducted to systematically use a set of universal criteria to evaluate the coursebooks used in high school English courses of the curriculum prepared by the Turkish Ministry of National Education. 


\section{Method}

Inasmuch as coursebook is probably the most commonly-used type of material for many teachers, selecting an appropriate coursebook for a language classroom carries an undeniable importance. Teachers are likely to either adapt the coursebook or use it as it is. Undoubtedly, in both cases, they always use it as guidance through the lesson. Despite the aforementioned significance of the coursebooks and the bulk of studies conducted on the effectiveness of the coursebooks down the years, there seem no studies have been conducted to investigate the effectiveness of the English language coursebooks used in English courses of Turkish public schools. In the current study, the three English coursebooks provided by Turkish Ministry of National Education to be used at the 2nd, 3rd and 4th grades of Turkish public elementary schools were taken into scrutiny to see to what extent they meet the requirements of Tomlinson and Masuhara's (2013) universal criteria. It is worth underlining that these three coursebooks have been approved and funded by the Turkish government, and they are the mostly used coursebooks for public primary school students. The details about the coursebooks we have evaluated are in Table 1. These coursebooks are used in 2019-2020 educational years by public schools' 2nd, 3rd and 4th grade students in Turkey. All of the courses contain 10 different units. Respectively, these courses contain 176, 190 and 192 pages in total. In this evaluation, after a short but effective discussion about which units to choose, we made a consensus on units 2 and 7 of the three coursebooks, since we believed that these two units were able to represent the other units in the books and these two units would be able to give a wider perception of the coursebooks.

Table 1. Public Elementary School Coursebooks

\begin{tabular}{ccc}
\hline Coursebook & Authors & Publisher \\
\hline $\begin{array}{c}\text { Elementary School English } \\
\text { Coursebook 2nd Grade }\end{array}$ & Ferahnaz Tan & Bilim ve Kültür Publishing \\
$\begin{array}{c}\text { Elementary School English } \\
\text { Coursebook 3rd Grade }\end{array}$ & $\begin{array}{c}\text { Feray Akkabak, Mehmet Zahit Kutlu, } \\
\text { Muhammet Turgay Kayıran, Pelin } \\
\text { Sağlam, Sevinc Karaköse }\end{array}$ & MEB Publishing \\
$\begin{array}{c}\text { Elementary School English } \\
\text { Coursebook 4th Grade }\end{array}$ & Ferahnaz Tan & FCM Publishing \\
\hline
\end{tabular}

\subsection{Data collection procedures}

The evaluators in this study adopted Tomlinson and Masuhara's (2013) set of universal criteria independently and in isolation to evaluate the English language learning coursebooks used at Turkish public elementary schools before collecting their data and achieving a consensus on their average scores. In the evaluation process, we discussed each criterion along with the effectiveness of the activities in two units (i.e., Unit 2 and Unit 7), provided explanations on the effectiveness of each unit in accordance of the set of 15 universal criteria, and finally ranked each criterion on a scale of 1 to 3: (1) unlikely to be effective in facilitating long-term acquisition, (2) likely to be partially effective in facilitating longterm acquisition, and (3) likely to be effective in facilitating long-term acquisition. It is worth noting that Tomlinson and Masuhara's (2013) set of universal criteria takes into account the potential effectiveness of the coursebooks in connection with what they believe paves the way for long-term acquisition of a foreign language (i.e. committed and purposeful interaction with the target language resulting in deep processing). They assert that focusing on short-term learning as a result of shallow processing would lead to potentially different evaluations and consequently divergent scoring on the part of the evaluators. 


\subsection{Evaluation of the coursebooks}

1. To what extent is the course likely to provide extensive exposure to English in use?

In this criterion, the evaluators can examine to what extent the coursebook is likely to provide extensive exposure to English in use, evaluating the length of the texts, the texts illustrating language points, authenticity of the text, adapted contents, accents, quotations, extracts from novels, and recordings of English as a lingua franca (ELF) users.

\begin{tabular}{|c|c|c|}
\hline Course & Score & Comments \\
\hline $\begin{array}{c}\text { Elementary School } \\
\text { English Coursebook } \\
\text { 2nd Grade }\end{array}$ & 1 & $\begin{array}{l}\text { Most of the exposure to English in both units is only listening activities. } \\
\text { However, there are no exposures to any reading texts in the both units; } \\
\text { only a few dialogues that are very short in Unit } 2 \text { and some activities that } \\
\text { present the target words in Unit } 7 \text {. The longest dialogue is on page } 24 \text { in } \\
\text { Unit 2, which contains greeting phrases. }\end{array}$ \\
\hline $\begin{array}{c}\text { Elementary School } \\
\text { English Coursebook } \\
\text { 3rd Grade }\end{array}$ & 2 & $\begin{array}{l}\text { The units contain various texts such as dialogues and songs. However, } \\
\text { most of the texts are given as individual sentences. On the other hand, } \\
\text { some texts seem to provide enough examples to introduce the language } \\
\text { point of the units. As a further matter, the main focus and reason for text } \\
\text { choice in the both units seems to illustrate the language points. In a text } \\
\text { on page } 42 \text { in Unit } 2 \text {, there is a text about Mustafa Kemal Ataturk, the } \\
\text { founder of the Turkish Republic. In both units there are dialogues that } \\
\text { represent real life scenarios, such as asking or giving directions. However, } \\
\text { there is no reference to, say, novels, stories or newspapers. }\end{array}$ \\
\hline $\begin{array}{c}\text { Elementary School } \\
\text { English Coursebook } \\
\text { 4th Grade }\end{array}$ & 1 & $\begin{array}{l}\text { In Unit } 2 \text {, the topic is nationalities. In this unit there could have been } \\
\text { extensive reading texts about nations or cultures; however, there are too } \\
\text { many short pieces of reading. In fact, they mostly consist of one or two } \\
\text { sentences. For example, the longest text on page } 25 \text { is an activity in which } \\
\text { students are asked to listen and fill in the blanks. Besides, in the text there } \\
\text { are too many blanks, hence we were not sure if this text could even be } \\
\text { considered as a text that could provide extensive exposure to English in } \\
\text { use. Moreover, most exposure to language seems to be short listening } \\
\text { activities (e.g., pages } 22 \& 26 \text { ), and a couple of short sentences (e.g., pages } \\
96 \& 97 \text { ). }\end{array}$ \\
\hline
\end{tabular}

2. To what extent is the course likely to engage the learners affectively?

In this criterion, any affective engagement, amusement, excitement, disturbance, stimulation, and habits in the contents of the materials can be taken into scrutiny in the coursebook.

\begin{tabular}{ccl}
\hline Course & Score & Comments \\
\hline $\begin{array}{c}\text { Elementary School } \\
\text { English Coursebook }\end{array}$ & 3 & $\begin{array}{l}\text { There are colorful and big illustrations of cartoon characters on page 20, } \\
\text { 2nd Grade }\end{array}$ \\
& $\begin{array}{l}\text { might be able to engage with affectively. There are also activities such as } \\
\text { singing on page 22 and playing games on page 25 which can engage them } \\
\text { affectively. Moreover, there are activities involving singing, playing }\end{array}$
\end{tabular}



Elementary School
English Coursebook
3rd Grade

Elementary School English Coursebook 4th Grade games and coloring which could help learners engage with lessons emotionally. It is worth stating that these factors are in accordance with affective engagement and in alignment with the learners' developmental stage.

3 Even though there are no emotionally engaging texts or materials, the illustrations and the variety of the activities could potentially keep the learners engaged as they are colorful, attention-getting and in various styles. There are also attempts that provide affectively engaging activities like talking about their own family on page 35 , singing, and acting out on page 39. Also there are activities that gamify the language item like puzzles and maps on pages 122 and 128 .

2 Although there are puzzle activities on pages 30-101 which seems to be engaging and amusing, they mainly provide language use or comprehension check. Apart from puzzles, there are mostly mechanical and repetitive activities such as matching and filling which could be boring after a while, so not engaging affectively. For example, in one listening activity in Unit 2 on page 24, the students are asked to listen and circle the cities they hear on the map given. There is neither pre-listening nor discussion after listening which could help them engage affectively. In each unit, there is a project time which could potentially engage students affectively. For example, in Unit 2, students are expected to make a puppet and puppeteer them while using the language items in the unit. In one task students are asked to put the right stickers beside the right job on page 106 and it would probably be entertaining to do. There is also a survey activity on page 103 where students are asked to survey their family members, which could potentially engage them affectively.

3. To what extent is the course likely to engage the learners cognitively?

In this criterion, the evaluators can examine whether the materials engage the learners cognitively, and whether the contents of the materials can make the users think analytically, imaginatively, and creatively. In addition, cognitively challenging questions, cognitively engaging, conflict negotiation, activities stimulating students to think, simulation of conflict negotiation, and stimulating thought and discussion about issues can be taken into close account.

\begin{tabular}{ccl}
\hline Course & Score & \multicolumn{1}{c}{ Comments } \\
\hline $\begin{array}{c}\text { Elementary School } \\
\text { English Coursebook } \\
\text { 2nd Grade }\end{array}$ & $1 \quad \begin{array}{l}\text { All of the tasks require specific answers which give no room for creativity } \\
\text { in the units. They consist of matching or ticking that requires no thinking } \\
\text { process. The materials given are not analytically prompting or } \\
\text { challenging. The learners are not expected to think critically about any of } \\
\text { the language items. The book in general possesses a consistency to serve } \\
\text { everything on a platter; it does less to nothing in order to encourage } \\
\text { learners to come up with creative ideas, let alone improving their } \\
\text { creativity. The units do not challenge the learners to think analytically, } \\
\text { imaginatively, or creatively. Most of the units are devoted to mechanical }\end{array}$
\end{tabular}




\section{Elementary School \\ English Coursebook 3rd Grade}

Elementary School

English Coursebook 4th Grade activities which serve as practice rather than prompting discoveries. Therefore, it does not allow learners to engage cognitively.

The only activity that could potentially engage the learners cognitively is on page 35 in which the learners are asked to talk about their family and to utter new sentences about themselves. In both units, the topic is not cognitively engaging. There is no need to think critically or analytically. Even though Unit 7 is more challenging, none of the activities are likely to stimulate the learners cognitively. There is an evident insufficiency of cognitively engaging materials and texts. Comprehension checks, grammar and vocabulary exercises dominate most of the units (e.g., pages 127-130).

1 In both units, mechanical activities seem to be more than the activities that could potentially engage the learners cognitively. Only 3 out of 23 activities are believed to be cognitively engaging. They include guessing game, project time activities on page 28 and the draw and write about yourself task on page 33. Other than these activities, the other ones make learners practice the language items with given answers which would make the tasks much simpler than it is supposed to be. Matching, completing the sentences or filling the gaps activities dominate the whole coursebook. Although there is a matching activity on page 103 that allows the learners to make assumptions about people's favorite jobs, this task is too simple for the learners' level and is less likely to challenge them critically. For example, in one activity in Unit 7 on page 100, students are asked to categorize nouns (jobs) and actions into two separate columns. This task could have been cognitively engaging; however, this task and the rest of the tasks are replete with close-ended questions. Hence, they do not challenge them to think out of the box!

4. To what extent is the course likely to provide an achievable challenge?

The criterion examines whether the contents are linguistically and cognitively easy, whether the learners are invited to come up with innovative ideas, whether preparation time is sufficient, whether completing sentences are tedious, whether answers can be potentially found in the texts without really having to think, whether easiness of the quizzes are obvious, whether the questions are to elicit target language or to challenge the learners, and whether there is any instruction on what to do with the activities. 


\begin{tabular}{|c|c|c|}
\hline Course & Score & Comments \\
\hline $\begin{array}{c}\text { Elementary School } \\
\text { English Coursebook } \\
\text { 2nd Grade }\end{array}$ & 1 & $\begin{array}{l}\text { Unit } 2 \text { consists of activities that require little to no challengeable tasks for } \\
\text { the learners. The activities are mostly focused on eliciting language items } \\
\text { rather than challenging the student (e.g., pages 23-24). These tasks have } \\
\text { simple answers which are mostly given to learners beforehand to let the } \\
\text { learners choose that makes it much simpler. Neither cognitive nor } \\
\text { affective challenges can be observed in the units. The difficulty level of } \\
\text { the activities in Unit } 7 \text { does not seem to be corresponding with the level of } \\
\text { the learners. The majority of the activities are too simple for the second } \\
\text { graders. }\end{array}$ \\
\hline $\begin{array}{c}\text { Elementary School } \\
\text { English Coursebook } \\
\text { 3rd Grade }\end{array}$ & 2 & $\begin{array}{l}\text { A somewhat challenging task can be seen on page } 35 \text { in which learners are } \\
\text { required to talk about their family. The rest of the tasks mostly consist of } \\
\text { linguistically and cognitively achievable mechanical tasks. However, Unit } \\
2 \text { seems to provide achievable challenges for the level and age of the } \\
\text { students. In contrast, Unit } 7 \text { provides only two activities that could be } \\
\text { considered as cognitively challenging on page } 122 \text { where students look at } \\
\text { the map to find some answers and a self-check activity on page } 129 \text {. Other } \\
\text { activities do not require much effort since the answers are given, which } \\
\text { makes the tasks linguistically and cognitively easy (e.g., pages } 118,119 \text {, } \\
\& 127 \text { ). }\end{array}$ \\
\hline $\begin{array}{c}\text { Elementary School } \\
\text { English Coursebook } \\
\text { 4th Grade }\end{array}$ & 1 & $\begin{array}{l}\text { There are many easy practice activities and tasks that are mostly simplified } \\
\text { by giving answers to choose from. For instance, on page } 27 \text {, there is a task } \\
\text { where learners are required to work in pairs and ask questions; however, } \\
\text { the answers are provided to students. Thus the task is made too achievable } \\
\text { for the level of the students. On page } 103 \text {, there are some short sentences } \\
\text { to match them to the jobs. They could have guessed the jobs on their own. } \\
\text { All other activities are linguistically easy. There is a task on page } 106 \\
\text { which might be confusing to the students because its instruction is very } \\
\text { short and not clear; the instruction is "self-assessment" and the students } \\
\text { are supposed to put a tick in the blanks on the table after finishing the unit. } \\
\text { There are not only issues in the instruction, but this task is too challenging } \\
\text { for fourth graders to achieve because the sentences given requires high- } \\
\text { level proficiency. }\end{array}$ \\
\hline
\end{tabular}

5. To what extent is the course likely to help learners to personalize their learning?

The criterion aims at looking whether the questions and activities ask the learners to give their views or opinions, and whether the users can relate texts and activities to their own lives. The questions inviting personal thoughts, and activities inviting the learners to make connections to their own experience, environment and lives are taken into consideration in this criterion.

\begin{tabular}{ccc}
\hline & Score & Comments \\
\hline $\begin{array}{c}\text { Elementary School } \\
\text { English Coursebook }\end{array}$ & 1 & $\begin{array}{l}\text { There are no activities that prompt learners to share their ideas and } \\
\text { 2nd Grade }\end{array}$ \\
opinions. However, there are 4 activities out of 20 which encourage \\
learners to connect their personal life at some level, such as
\end{tabular}




\author{
Elementary School \\ English Coursebook \\ 3rd Grade
}

Elementary School
English Coursebook
4th Grade personalization on page 22 in which students are asked to introduce themselves in target language. Moreover, in the workbook section of the unit there are two personalized tasks, including drawing one's self portrait and friend on pages 28 and 29 respectively. And lastly on page 26 there is a task asking students to make a badge with their name on it. These activities are outnumbered by different matching and box ticking activities. In Unit 7, there is only one activity that might be hinting to personalization of the task to some extent by saying "point your own body parts". However, this questionable hint to personalization does not obviously go beyond the surface level. There are potentially many tasks which could have been personalized; however, the book fails to make use of these opportunities. For example, on page 105, instead of coloring a random girl/boy, students could have been instructed to color the picture resembling their own features.

$1 \quad$ Talking about family and family poster assignment on pages 35 and 42 respectively are only two activities that require a personal answer from the learners in Unit 2. Nor does the other unit appropriately provide personalization except an assignment on page 130, which asks students to prepare a map of their city/village or town and describe it in groups.

There is no real attempt to invite the learners to share their personal experience, opinion or views. On the contrary, they are asked to learn and practice language items or ask questions about people unconnected to their lives. There are opportunities in which students' views could be inquired, but the coursebook does not make use of these occasions. For example, on page 27 , students are asked to work in pairs and answer the questions given about nationalities. However, they are supposed to answer the questions about someone else rather than themselves. In a different example, on page 96 , learners are asked to talk about imaginary people's jobs that they are not related with. The one and only activity is on page 103, where students are required to do a survey about their family members' occupations.

6. To what extent is the course likely to help the learners to make discoveries about how English is typically used?

In this criterion, the evaluators can look at any activities that ask learners to guess from evidence, any consciousness-raising activities requiring the learners to make discoveries and to talk about any discoveries they have made, and any questions asking the learners to identify types of expressions.

\begin{tabular}{ccl}
\hline Course & Score & Comments \\
\hline $\begin{array}{c}\text { Elementary School } \\
\text { English Coursebook }\end{array}$ & 1 & $\begin{array}{l}\text { There are no attempts to let the learners think critically about the language } \\
\text { itself, and to help them make discoveries about the target language. There } \\
\text { are neither open ended questions nor tasks that require the views of the } \\
\text { learners, which prevents learners to come up with rules or ideas about how } \\
\text { English is typically used. In fact, it does not even let them question the } \\
\text { language items. The tasks in the units assess only what the learners already }\end{array}$ \\
&
\end{tabular}




\begin{tabular}{ll}
\hline & $\begin{array}{l}\text { know and they do not invite them to make discoveries for themselves, nor } \\
\text { does it allow them to make predictions (e.g., page 24, task 9). }\end{array}$ \\
$\begin{array}{c}\text { Elementary School } \\
\text { English Coursebook } \\
\text { 3rd Grade }\end{array}$ & $\begin{array}{l}\text { In none of the units students are expected to make inquiries about how } \\
\text { English is typically used. They do not go beyond exposure, and learners } \\
\text { are not enabled to observe the language use in detail. The one and only } \\
\text { observable part that can raise awareness is a short note on page 31, where } \\
\text { students are introduced to typical use of family member names. }\end{array}$ \\
Elementary School & $\begin{array}{l}\text { The units do nothing to provide examples on how English is typically } \\
\text { used. The monotonic sentences and repetitive forms (e.g., pages } 25,27, \& \\
\text { 30) prevent involving the learners to make discoveries on their own. Most } \\
\text { of the activities are practice activities; the students are not given any } \\
\text { opportunity to make predictions about anything. }\end{array}$ \\
&
\end{tabular}

7. To what extent is the course likely to provide opportunities to use the target language for communication?

In evaluating whether the materials provide opportunities for the users to use the target language for communication, the evaluators can look at the extent skill-based (e.g., speaking/writing) activities could result in achieving non-linguistic outcomes, whether there is any specification of audience or intended outcomes in speaking/writing activities, whether the learners are told what to say or how to say, or whether they are merely practice or communicative activities.

\begin{tabular}{ccl}
\hline Course & Score & \multicolumn{1}{c}{ Comments } \\
\hline $\begin{array}{c}\text { Elementary School } \\
\text { English Coursebook } \\
\text { 2nd Grade }\end{array}$ & $1 \quad \begin{array}{l}\text { Even though the topic of Unit } 2 \text { is 'greetings', there are very few activities } \\
\text { for students to use the language in communication. In both units, the } \\
\text { activities that aim to provide opportunities to use the target language for } \\
\text { communication are scarce. In Unit 2, there are only four tasks that have } \\
\text { the potential to trigger communication, such as introducing one's self and } \\
\text { friend on page 22. However, in these communicative tasks students are } \\
\text { only allowed to practice pre-given structures and language items rather } \\
\text { than real communication. The rest of the activities only requires individual } \\
\text { practice. }\end{array}$
\end{tabular}




\section{Elementary School \\ English Coursebook 3rd Grade}

Elementary School

English Coursebook 4th Grade
In Unit 2, the authors seem to be concerned with introducing the language items rather than the use of these items for communicative purposes. The unit does not provide opportunities to use the language in communication except three activities on pages 35,122 , \& 130. For example, on page 35, the learners are asked to talk about their family. Moreover, the authors seem to be undermining the learners and making the tasks simpler by excluding production from the learners. Hence, this does not help students in using the target language for communicative purposes. On page 122, there is an activity named talking about the children on the map, which asks students to prepare a map of their city/village or town and describe it in groups. Unfortunately pre-designed dialogues take up the most part of the activities, and the focus is on practicing structured use of language which cannot truly provide effective use of target language for communication.

2 There is an attempt to help learners use the target language for communication such as guessing game and project time on page 28 . However, most of these activities that could promote communication are pre-designed, which cannot lead to natural communication. In some cases in reading activities, students are asked to work in pairs, read the text and act out the dialogues, which might provide opportunities to use the target language for communication. Nonetheless, the number of such kinds of activities is simply insufficient, and that these activities provide scripted communication.

8. To what extent is the course likely to help the learners to develop cultural awareness?

In order to answer this question, the evaluators can focus on whether the content of the materials helps the users develop greater awareness of the cultures of other countries or of their own country, whether only cultural knowledge is transmitted without awareness-raising, skills development, experiential activities or discussion, whether activities are to raise awareness of the self and others, whether there is a representation of any culture other than native-speakers, and whether there is any stereotyping.

\begin{tabular}{|c|c|c|}
\hline Course & Score & Comments \\
\hline $\begin{array}{c}\text { Elementary School } \\
\text { English Coursebook } \\
\text { 2nd Grade }\end{array}$ & 1 & $\begin{array}{l}\text { There are no attempts to raise cultural awareness in the units. For example, } \\
\text { Unit } 2 \text { is about greeting; however, the tasks do not let students think } \\
\text { critically about the way they can use the language to greet and the way } \\
\text { other cultures use the language while greeting others. Out of } 20 \text { tasks there } \\
\text { is only one task in which some local names, such as Ayşe and Hasan, can } \\
\text { be seen (page 22, task 6). The excessive use of foreign names dominates } \\
\text { the units. In all of the illustrations there is not even a representation of } \\
\text { people with different skin colors. In a sense it can be concluded that the } \\
\text { units do not give the required importance to development of cultural } \\
\text { awareness. The coursebook not only lacks the key aspects to raise } \\
\text { awareness of other cultures but it also mostly ignores Turkish culture as } \\
\text { well. }\end{array}$ \\
\hline
\end{tabular}




\section{Elementary School \\ English Coursebook 3rd Grade}

Elementary School

English Coursebook 4th Grade

\section{1}

At the end of Unit 2, there is an activity about the first prime minister of Turkey which could have been used as awareness raising activity; however, it is included to enable only practice of language items. In general, there are few representations of other cultures in the units except one activity that involves foreign names on page 33 . However, there are no places for discussing the names used in different countries. Although there are some cultural elements from the native perspectives such as cities in Turkey, and Turkish names or illustrations of mosques on pages 117, 118 , and 129 , the units seem to fail to instruct or guide the learners to develop cultural awareness.

Since the topic of Unit 2 is nationalities, some cultural elements can be seen on page 25 , in which there is a listening and matching task accompanying different cartoon illustrations from different cultures. Moreover, all the audios for the listening activities are only in British accent. What follows are some practice activities for vocabulary (e.g., nationalities, countries, and directions), language items (agreeing and disagreeing) and some role-play activities. Yet none of them gives cultural information or raises cultural awareness. It is worth mentioning that some illustrations seem to be a little stereotypical. For example, on page 33, there is a portrait of a white British, red-haired and blue-eyed girl. Also, there is an Asian boy with yellow skin and black hair. In task 10 in Unit 7, there is an illustration of a traditional North American barn, and the subject of the task is Mr. Jenkins. There could have been some questions that would encourage students to compare the farm life of Turkish and American people. However, the learners are only asked to answer the questions with given answers. Thus, even though there are opportunities to discuss or raise awareness about cultures, they are not effectively exploited. Overall, we can say that the coursebook does not aim to raise cultural awareness.

9. To what extent is the course likely to help the learners to make use of the English environment outside the classroom?

In answering this question, the evaluators can scrutinize whether there are any attempts made to encourage the learners to make use of English in their actual or virtual environments outside the classroom, and whether the users are asked to do something with the studied materials outside of the classroom.

\begin{tabular}{ccl}
\hline Course & Score & \multicolumn{1}{c}{ Comments } \\
\hline $\begin{array}{c}\text { Elementary School } \\
\text { English Coursebook } \\
\text { 2nd Grade }\end{array}$ & $\begin{array}{l}\text { The topic of Unit } 2 \text { involves everyday situations, but the instructions do } \\
\text { not guide learners to use the things they learn outside the classroom in the } \\
\text { real environment. The instructions in the coursebook are not well } \\
\text { constructed enough to allow students to work on their own without } \\
\text { guidance outside the classroom. For example, on page 27, task 1, the } \\
\text { instruction is too short and comes off as demanding. In fact, this deficiency } \\
\text { could be observed in all of the tasks in the units. Hence, no clear attempt } \\
\text { is made to encourage the learners to make use of English in their actual or } \\
\text { virtual environments outside the classroom. }\end{array}$
\end{tabular}




\section{Elementary School \\ English Coursebook 3rd Grade}

Elementary School

English Coursebook 4th Grade
The only two activities that could be considered as potentially encouraging the learners to make use of English beyond the classroom are on pages 42 and 130. No other example is seen in the units to provide English use in their actual or virtual environments outside of the classroom.

In the units, the tasks mostly focus on the immediate outcome rather than lifelong learning. They are mostly designed for practicing the language items in the classroom environment and cannot be adapted to the virtual or actual environment of the learners. Thus, we can say that the units do not encourage or lead learners to make use of English outside of the classroom environment. There are only two out of forty-two activities can potentially encourage learners to make use of English outside of the classroom. The first one is on page 100, in which students are asked to prepare a poster at home about their parents and their jobs. And in the other one on page 103, students are asked to survey their family members. It is only in these scenarios that students would be able to use English outside the classroom environment.

10. To what extent is the course likely to cater for the needs of all the learners?

This question aims at clarifying whether the activities are one-size-fits-all, investigating whether the contents presume that all students are, say, internet users, well-educated, urban middle-class westerners, frequent international travelers, city dwellers, looking for good eating experiences and being ecologically aware. The learning styles of the users are also taken into consideration.

\begin{tabular}{|c|c|c|}
\hline Course & Score & Comments \\
\hline $\begin{array}{c}\text { Elementary School } \\
\text { English Coursebook } \\
\text { 2nd Grade }\end{array}$ & 1 & $\begin{array}{l}\text { Through the units, there is no use of media or technological devices other } \\
\text { than the coursebook itself. This makes us conclude that the coursebook is } \\
\text { probably designed for the middle or lower class in the society, assuming } \\
\text { that they do not possess the required facilities. Other than the economic } \\
\text { needs, there is an illustration of a boy with a leg cast on page } 24 \text {. This } \\
\text { might be a way to raise awareness towards learners who have special } \\
\text { needs. As the coursebook is government-provided and available for all of } \\
\text { the students from different economic, social and cultural backgrounds, the } \\
\text { activities seem to be one-size-fits-all, and do very little to appropriately } \\
\text { take into consideration the needs of the individual students. }\end{array}$ \\
\hline $\begin{array}{c}\text { Elementary School } \\
\text { English Coursebook } \\
\text { 3rd Grade }\end{array}$ & 2 & $\begin{array}{l}\text { Similar to the other coursebook series of the elementary coursebooks, the } \\
\text { audio tracks of the listening tasks are not provided accompanying the } \\
\text { coursebooks, which could be problematic for students with special needs. } \\
\text { The book provides some materials for crafting tasks within the coursebook } \\
\text { which makes them more user-friendly for learners from different } \\
\text { economic backgrounds. }\end{array}$ \\
\hline $\begin{array}{c}\text { Elementary School } \\
\text { English Coursebook } \\
\text { 4th Grade }\end{array}$ & 1 & $\begin{array}{l}\text { The materials and activities in the coursebook are seemingly inappropriate } \\
\text { to the students' proficiency level. They are too easy and so insufficiently } \\
\text { engaging. Additionally, the absence of real life scenarios was prominent. } \\
\text { The assumption in the units seems to be that the learners are beginners at } \\
\text { English who have access to different media platforms such as technology } \\
\text { and the internet. That is why the listening tracks are only accessible on the } \\
\text { internet. Moreover, the units overlook learners who may have special }\end{array}$ \\
\hline
\end{tabular}


needs, and do not provide any material or transcript for them. However, there is an illustration on page 31 , indicating a girl in a wheelchair and it represents a group of our community that is underrepresented. However, in general, the coursebook completely ignores the special education students. There is nothing that would help or guide learners with special needs. The book is seemingly designed for an ideal middle class group of learners. However, it could be more user-friendly regarding the different learning style preferences by providing a different variety of activities, considering the learning styles of the users.

11. To what extent is the course likely to provide the flexibility needed for effective localization?

This criterion seeks to clarify whether the users relate the texts, tasks, or topics in the materials to their own countries or their own localities, whether there is any localized conflict resolution simulation, and whether the activities invite comparisons and connections with the learner's country.

\begin{tabular}{|c|c|c|}
\hline Course & Score & Comments \\
\hline $\begin{array}{c}\text { Elementary School } \\
\text { English Coursebook } \\
\text { 2nd Grade }\end{array}$ & 1 & $\begin{array}{l}\text { There are not any relatable texts, illustrations or tasks for the learners to } \\
\text { connect with their own localities in the units. The topics such as having a } \\
\text { dog inside the house are relatively unusual in most of the Turkish } \\
\text { households, and the learners might have difficulty localizing the topic. } \\
\text { Even though there are some illustrations of unusual sights in the units, } \\
\text { there are no effective activities for localization. Furthermore, there are no } \\
\text { activities to involve the learners to look at the premises from the local } \\
\text { perspectives. }\end{array}$ \\
\hline $\begin{array}{c}\text { Elementary School } \\
\text { English Coursebook } \\
\text { 3rd Grade }\end{array}$ & 3 & $\begin{array}{l}\text { The local culture of the source language is considered in the units, ranging } \\
\text { from the names, the attires of the people in the illustrations, to some topics } \\
\text { from local culture on pages } 37 \text { and } 42 \text {. The language items could have } \\
\text { been presented in local scenarios, or contexts to enable learners to } \\
\text { compare and contrast with his/her own local contexts. Although the lack } \\
\text { of local contexts or scenarios is eminent, yet the flexibility for effective } \\
\text { localization is provided throughout the unit. }\end{array}$ \\
\hline $\begin{array}{c}\text { Elementary School } \\
\text { English Coursebook } \\
\text { 4th Grade }\end{array}$ & 2 & $\begin{array}{l}\text { Unit } 2 \text { contains several local representations. For instance, on page } 24 \text {, } \\
\text { there is a map of Turkey, and on page } 31 \text { there are questions about famous } \\
\text { people from around the world and one of them is from Turkey. There are } \\
\text { some illustrations that represent local elements, such as Turkish bread, and } \\
\text { a local celebrity. However, the names used in the activities are mostly } \\
\text { foreign names with a few Turkish names on pages } 96,98 \text {, and } 102 \text {. There } \\
\text { is an illustration of a traditional North American barn on task 10. Instead } \\
\text { of this barn, the illustration and the task could have used by indicating } \\
\text { something more similar to our culture so that students could relate more } \\
\text { to the task. Therefore, it can be concluded that the units do not provide } \\
\text { sufficient flexibility for localization. }\end{array}$ \\
\hline
\end{tabular}

12. To what extent is the course likely to help the learners to continue to learn English after the course?

The purpose of this question is to see whether there is any attempt to develop the skills, resources, or enthusiasms that would help the users to continue to learn English after their course, whether there is 
any encouragement for autonomy during or after the course, whether there are any activities teaching real-life skills and strategies, and whether there are any contents encouraging self-study.

\begin{tabular}{|c|c|c|}
\hline Course & Score & Comments \\
\hline $\begin{array}{c}\text { Elementary School } \\
\text { English Coursebook } \\
\text { 2nd Grade }\end{array}$ & 1 & $\begin{array}{l}\text { The book in general makes the students confined in the classroom context } \\
\text { by not providing any kind of resources for further learning. Most of the } \\
\text { activities involve listening; however, audio or tracks are not provided to } \\
\text { the learners. Therefore, they cannot practice or study after the course is } \\
\text { finished. The activities in the workbook are solely practice activities which } \\
\text { consist of mechanical practices such as filling the gaps or matching, and } \\
\text { do not seem to be able to create an opportunity for them to effectively } \\
\text { study after the course, or to lead to long-term learning. In addition, there } \\
\text { are no suggested links or materials to benefit from or to improve a } \\
\text { particular skill such as reading or listening outside the classroom in the } \\
\text { coursebook. }\end{array}$ \\
\hline $\begin{array}{c}\text { Elementary School } \\
\text { English Coursebook } \\
\text { 3rd Grade }\end{array}$ & 1 & $\begin{array}{l}\text { Even though not directly stated, the goal of the coursebook does not seem } \\
\text { to be enabling a lifelong language education. At the end of the coursebook } \\
\text { there are some extracurricular exercises that can in a sense provide } \\
\text { materials that could be made use of after the course. Yet other than these } \\
\text { examples there are no recommendations for further language learning to } \\
\text { continue after they are done with the course. }\end{array}$ \\
\hline $\begin{array}{c}\text { Elementary School } \\
\text { English Coursebook } \\
\text { 4th Grade }\end{array}$ & 1 & $\begin{array}{l}\text { The coursebook does not encourage autonomy and does not pave the way } \\
\text { for the learners to take responsibility for their learning. Even in some } \\
\text { cases, although the students are expected to conduct self-assessment by } \\
\text { themselves (e.g., page } 34 \text { ), the instructions are too difficult for them to } \\
\text { understand. Hence, they even will need teacher help to accomplish this } \\
\text { section. As language learning is a lifelong process, the student autonomy } \\
\text { in this coursebook is not encouraged, and the lack of guidance towards } \\
\text { learning after the course is evident. }\end{array}$ \\
\hline
\end{tabular}

13. To what extent is the course likely to help learners to use ELF?

In this criterion, the evaluators can investigate whether there are, say, any novels, literary works, photos, or English accent from non-native speaker countries. Any contents creating the ELF awareness can be taken into account.

\begin{tabular}{ccl}
\hline Course & Score & Comments \\
\hline $\begin{array}{c}\text { Elementary School } \\
\text { English Coursebook } \\
\text { 2nd Grade }\end{array}$ & 1 & $\begin{array}{l}\text { The dominant accent in the audios is British English. Moreover, from the } \\
\text { vocabulary and illustrations in the coursebook the main focus seems to be } \\
\text { either on standard American or British English. By just looking at the } \\
\text { vocabulary items such as colour (e.g., page 97, it is possible to realize that } \\
\text { the coursebook focuses mostly on British English. Hence, there are no } \\
\text { varieties apart from the native Englishes, and the coursebook does not } \\
\text { seem to create ELF awareness in the learners. }\end{array}$
\end{tabular}




\author{
Elementary School \\ English Coursebook \\ 3rd Grade
}

Elementary School

English Coursebook 4th Grade
Throughout the units the language focus seems to be on British English (e.g., the use of mum and colour on pages $31 \& 130$ respectively). Moreover, the accents used in the listening tracks are all standard British accents. In addition, the dialogues and conversations are based on standard English. The representations of ELF cannot be seen through the units. Thus we can come to the conclusion that the units fail to familiarize the learners with EFL.

1 Most of the spoken texts are interactions between Turkish people. As the topic in Unit 2 is nationalities, there are some examples of speakers from other countries. For example, on page 27, students are asked to pair up and make a dialogue according to the given questions and information. This task includes characters from foreign countries. However, overall language is standard British English and the audios for the listening tasks involve British English, too. In conclusion, the different representations of EFL cannot be seen throughout the units, and hence no attempt is made to create the ELF awareness.

14. To what extent is the course likely to help learners to become effective communicators in English?

This criterion takes into scrutiny any activates that help learners to use English to achieve effective outcomes, any activities that focus on outcomes rather than outputs, any opportunities to raise awareness or discuss effects, repairs, or strategies in communication, any critical reading or discussion-based activities, any activities asking for outcome of the negotiation, any activities focusing on appropriacy and effectiveness rather than only accuracy, and any activities that help learners achieve communicative effectiveness.

\begin{tabular}{|c|c|c|}
\hline Course & Score & Comments \\
\hline $\begin{array}{c}\text { Elementary School } \\
\text { English Coursebook } \\
\text { 2nd Grade }\end{array}$ & 1 & $\begin{array}{l}\text { There are no activities that provide opportunities for real life } \\
\text { communication. The main focus is on accuracy and output rather than help } \\
\text { learners achieve impactful outcomes. Structured communication models } \\
\text { seem to limit learners' autonomy (e.g., page } 24 \text {, task 9). Therefore, the } \\
\text { coursebook does not seem to help learners become effective } \\
\text { communicators in English. There are no dialogues in Unit } 7 \text {. Additionally, } \\
\text { there are no tasks that could enable learners to use the language in } \\
\text { communication, let alone improve their communication effectiveness. } \\
\text { Hence, the focus is not on guiding the learners towards being effective } \\
\text { communicators; instead, the focus is on the accuracy of production. }\end{array}$ \\
\hline $\begin{array}{c}\text { Elementary School } \\
\text { English Coursebook } \\
\text { 3rd Grade }\end{array}$ & 1 & $\begin{array}{l}\text { The only example of real communication is on page } 35 \text {, in which the } \\
\text { learners need to talk about their family. That aside, other communicative } \\
\text { activities only promote predesigned language utterances such as listen and } \\
\text { repeat the dialogue tasks on pages } 34-36 \text {. The focus is on the accuracy and } \\
\text { practicing of the language items rather than the efficiency of the } \\
\text { communication or its outcomes. There are some tasks for students to act } \\
\text { out the dialogues on pages } 124,125 \text {, and } 126 \text {. However, these activities } \\
\text { similarly focus on accuracy and practicing language items and not on } \\
\text { effective communication use. The only activity which can extract real } \\
\text { opinion from learners is on page } 122 \text {. }\end{array}$ \\
\hline
\end{tabular}


Elementary School

English Coursebook 4th Grade
1

The focus of the units is on the accuracy of reception and production. There is no attempt in helping students to achieve an outcome to be fluent since all of the production activities are guided (e.g., page 27). The communication activities focus around output and do little to nothing to prompt students to use the language freely for communicative purposes. For example, on page 97, task 6, students are asked to work in pairs while asking and answering questions about the pictures in the activity. Even though there is no instruction to use the same sentences, students would be confined with such kinds of question forms. In a different acting out activity on page 99 , there is a pre-designed speech provided to students to use while acting out. Such kinds of constraining activities are less likely to help them become effective communicators in English.

15. To what extent is the course likely to achieve its stated objectives?

This question measures to what extend the claims put forward by the authors are reflected in the coursebooks.

\begin{tabular}{|c|c|c|}
\hline Course & Score & Comments \\
\hline $\begin{array}{c}\text { Elementary School } \\
\text { English Coursebook } \\
\text { 2nd Grade }\end{array}$ & 1 & $\begin{array}{l}\text { Although some objectives are given on the first page of Unit } 2 \text {, they do } \\
\text { not seem to be very clear and professionally written. They seem to be like } \\
\text { topics from the unit rather than objectives. These include asking } \\
\text { someone's name, greeting and meeting people. However, if accepted as } \\
\text { the objectives, at some level throughout the units, the students are } \\
\text { provided with tasks that aim at achieving these objectives (e.g., pages } 22 \\
\& 23 \text {, tasks } 6 \text { \& 7). In comparison to Unit } 2 \text { objectives, the ones in Unit } 7 \\
\text { are not achievable, and are not the aims of the activities in the unit. Hence, } \\
\text { the objective do not relate to the main topic of the unit. }\end{array}$ \\
\hline $\begin{array}{c}\text { Elementary School } \\
\text { English Coursebook } \\
\text { 3rd Grade }\end{array}$ & - & $\begin{array}{l}\text { The coursebook does not state any objectives for the units or the tasks. } \\
\text { Thus, we could not evaluate this criterion. }\end{array}$ \\
\hline $\begin{array}{c}\text { Elementary School } \\
\text { English Coursebook } \\
\text { 4th Grade }\end{array}$ & 1 & $\begin{array}{l}\text { In this book at the beginning of every unit there seem to be some short } \\
\text { objectives. However, even though there are activities that serve them, the } \\
\text { given objectives at the beginning of the unit are very generalized and non- } \\
\text { detailed. In Unit } 7 \text {, the objectives are vastly generalized as well (e.g., } \\
\text { describing what people do and expressing what people like, and making } \\
\text { inquiries). The objectives are so non-detailed that they could be applied to } \\
\text { different topics. Therefore, we cannot say that it truly achieves its stated } \\
\text { objectives. }\end{array}$ \\
\hline
\end{tabular}

\section{Discussion}

This study sought to evaluate all three public elementary school coursebooks used in English courses of the curriculum prepared by the Turkish Ministry of National Education, implementing Tomlinson and Masuhara's (2013) set of 15 universal coursebook evaluation criteria. The coursebooks were government-provided English books being used at $2^{\text {nd }}, 3^{\text {rd }}$, and $4^{\text {th }}$ grades of public elementary schools 
in Turkey. The overall averages of the coursebooks are indicated in Table 2. As evident, the average scores of the all three coursebook are quite low. The third grade English coursebook was indicated to have the highest average scores $(M=1.5)$, while the second grade English coursebook has the lowest average score $(\mathrm{M}=1.1)$.

Table 2. The average scores of the coursebooks

\begin{tabular}{|c|c|}
\hline Coursebooks & Average Scores \\
\hline $\begin{array}{l}\text { Elementary School English } \\
\text { Coursebook 2nd Grade }\end{array}$ & Overall: $1.1=$ unlikely to be very effective in facilitating long-term acquisition \\
\hline $\begin{array}{l}\text { Elementary School English } \\
\text { Coursebook }\end{array}$ & Overall: $1.5^{1}=$ unlikely to be very effective in facilitating long-term acquisition \\
\hline 3rd Grade & \\
\hline $\begin{array}{l}\text { Elementary School English } \\
\text { Coursebook }\end{array}$ & Overall: $1.2=$ unlikely to be very effective in facilitating long-term acquisition \\
\hline 4th Grade & \\
\hline
\end{tabular}

${ }^{1}$ While calculating the average points of the rankings, we excluded the last criteria since the rank was unclear due to lack of objectives.

The first criterion in our evaluation process was the extent the coursebooks provide extensive exposure to English in use. In the current study, the evaluation indicated that the government-provided 2nd grade English coursebook is seriously deficient in contributing sufficient exposure to English. The majority of the exposure is constrained to listening activities without the audio transcripts. Hence, the exposure to English in use in general is not sustained throughout the units. In the case of the 3rd grade English coursebook, the dialogues and songs are included as reading texts and dialogues. The language point of the units seems to be the driving force for the material inclusion. However, the presentation of the language point through repetitive examples could help to provide extensive exposure to the target language to some extent. After some improvement in the third grade English coursebook in terms of providing exposure to English in use, the $4^{\text {th }}$ grade exposure to English in the coursebook was indicated to be quite unsatisfactory. In addition, there is not even a single solid paragraph that could provide extensive reading exposure to the students; the texts are too short and easy for the level of the students. In a nutshell, the evaluation indicated that none of the three coursebooks is likely to lead to the effective long-term acquisition of English.

In the second criterion, the main focus is on providing affective engagement, using the visuals, types and contents of the activities, and their alignment with the learners' level of interest and age. The evaluation indicated that the coursebook for the $2^{\text {nd }}$ grade was replete with many colorful and big illustrations that can catch the learners` attention, accompanying singing and playing games. As for the $3^{\text {rd }}$ grade, the coursebook outperforms in providing affective engagement with the various illustrations. Shortly, the coursebook is deemed to be visually enjoyable, and there are more interesting materials in this coursebook compared to the $2^{\text {nd }}$ and $4^{\text {th }}$ grades, such as pair works, acting outs, puzzles, maps or personal questions. The $4^{\text {th }}$ grade coursebook also provides, say, some puzzles, pair work, and project activities; however, the number of mechanical activities abounds in the coursebook.

Contemplative and critically engaging contents of the materials are the main focus of the third criterion. The $2^{\text {nd }}$ grade coursebook had a high consistency in terms of simplicity and easiness of the contents. However, the long term learning cannot be achieved if the coursebook does nothing to enable 
the learners to think critically and creatively. The 3rd grade coursebook is quite enjoyable with its various materials; however, the topics are not so engaging. Moreover, the tasks are not designed to enable students to think critically, creatively or analytically. The main focus is on comprehension checks and vocabulary exercises rather than pave the way for the thought-provoking activities. A similar situation is evident in the $4^{\text {th }}$ grade coursebook; the activities do not go beyond matching, filling or completing with the given answers. For this reason, the coursebook cannot possibly engage the learner cognitively. As for the fourth criterion, all of the coursebooks are linguistically and cognitively very easy, and there are only a few activities in all three coursebooks in which the learners are invited to come up with innovative ideas (e.g., project times in the $4^{\text {th }}$ grade coursebook). In the instructions, in general, no information is given about the preparation time. The overall activities are simplified by answers provided without really inviting the leaner to think critically. Hence, there are no attempts to purposefully challenge the learners linguistically or cognitively. In the fifth criterion, all three coursebooks are disappointing since there are only few activities asking the learners to give their views or opinions. Even though the topics are relatable, the personalization of these topics does not seem to be the main goal of the coursebook. Meanwhile it is now a common knowledge that long-term learning cannot occur if not personalized (Tomlinson, 2013). That is disappointing to find that there are very rare occasions where the learners are enabled to make connections to their own experience, environment and lives.

As for the sixth criterion, the predetermined answers and simplified activities in all coursebooks are not likely to help learners guess or make discoveries about how English is typically used. Even though there are opportunities to, say, ask questions and to identify types of expressions, these opportunities are not made use of in the coursebooks. In the seventh criterion, the majority of the activities are for individual work and the ones designed for pair work are merely there for achieving linguistic outcomes, in which the learners are told what to say for achieving accurate results and practicing the language point. The $4^{\text {th }}$ grade coursebook possesses more activities compared to the first two coursebooks. However, the designs of the units present a very limited use of the structure or use of English. Hence, it will eventually incapacitate the learners to use language creatively by limiting or forcing them into using the same structures. Considering the eighth criterion, the majority of the illustrations and other materials are void of cultural elements. For example, other than a few exceptions, the illustrations represent only one type of race, skin color, and hair. In addition, in these exceptional cases the cultural knowledge is only transmitted, and there are no activities, or discussions to help learners raise cultural awareness of the self and others.

With the focus on the ninth criterion, none of the coursebooks was found to be able to provide sufficient instructions or materials to encourage the use of target language outside the classroom environment. They are very few instances in which learners are asked to make use of English in their actual or virtual environments outside the classroom. The likelihood of catering for the needs of all of the learners is the concern of the tenth criteria. Results showed that the contents of the third grade coursebook seem to presume that all students are lower class citizens who do not have access to the internet or even a CD player since there are no DVDs or CDs accompanying the coursebook. Interestingly, we were able to access the audio tracks from a website on the internet; however, the website does not belong to the publishers of the coursebook.

Regarding the eleventh criterion, it was found that the users could potentially relate the texts, tasks, or topics in the materials to their own countries or their own localities. However, there are no activities that invite comparisons and connections with the learners' countries. The other two coursebooks similarly were not found very successful in fulfilling the requirements of this criterion. All of three government provided coursebooks for elementary schools were found lacking the requirements of the twelfth criterion. Indeed, there are no attempts to develop the skills, resources, or the enthusiasm that 
would help the users to continue to learn English after the course in the coursebooks. The given answers and lack of strategy or skill development are less likely to do anything for autonomy that would help them keep learning during or after the course. There are no materials other than standard British English in the coursebooks. Nor were there any texts or accents in listening files from non-native speaking countries. In that sense none of the coursebooks could help to create the ELF awareness, which was the thirteenth criteria in the study. Similar to the other criteria, in the fourteenth criterion, none of the coursebooks was found to be concerned with raising strategies in communication either. Instead, they were found to be more concerned with eliciting the accurate outcomes for the learners. For this reason, that is a disappointing reality that government-provided elementary coursebooks do not seem to be able to provide opportunities to use the target language for communication. Regarding the last criterion, it can be said that at the beginning of each unit in the second and fourth grade coursebooks, there are statements that could be considered as objectives. Yet the majority of these objectives are either too general or to some extent irrelevant to the contents of the coursebooks. Added to that, it is worth stating that the present objectives are haphazardly, rather than professionally, included in the coursebooks.

\subsection{General features of the coursebook reviewed}

In sum, there are a couple of positive features of the evaluated coursebooks. They are as follows:

\subsubsection{The Layout and listening skill}

The units include many listening tasks, and the majority begins with listening skill to provide input for the learners. There cannot be output without input and since these coursebooks will most likely be the first introduction of a foreign language for many students who use them, this trait gains even more importance in the coursebooks. Besides, some listening tasks in the coursebooks can enable learners to enhance their pronunciation skills by giving many opportunities to practice.

\subsubsection{Illustrations in use}

The vast integration of the colorful illustration is another positive feature of the coursebooks. In fact, none of Tomlinson and Masuhara's (2013) set of universal criteria directly focuses on the visual aspect of the coursebooks. Given the fact that the potential users of the target coursebooks are young learners aged 8 to 10 years old, the evaluation of this essential facet can take on an added importance. In general, the use of the illustrations in the coursebooks to either gather attention or trigger engagement seems to be highly efficient.

\subsubsection{Affective engagement}

Since the coursebooks target younger audience, as aforementioned, there are many puzzles, songs and crafting tasks in the evaluated units, particularly in the third grade coursebook that make the tasks and activities quite entertaining. The crafting activities in the coursebooks possess a high potential to catch learners' attention to the topics and keep them affectively occupied.

In fact, the units we have covered were mostly filled with colorful drawings, illustrations and entertaining tasks that make the coursebooks seem appealing to the students and teachers at first sight. Nonetheless, throughout the evaluation process it was proved that these units were void of many crucial aspects of effective language acquisition. Indeed, the evaluation of the coursebooks indicated some negative features of them. In our review, unfortunately, there are too many negative features that may hinder long term language acquisition. The evaluation indicated that the Turkish public elementary English coursebooks are void of a number of important aspects of language acquisition: the communication-based activities, continuation of using English outside of the classroom, discovery enhancing input and extensive exposure to English. It seems that the main focus of the coursebooks is on the accuracy and linguistic output rather than effective outcomes, meaningful communication and 
long term language acquisition. Most of the activities in all of the coursebooks contain practice activities, with no place for productivity and autonomy on the part of the students, which causes deficiencies related to the absence of an appropriate exposure and model for language use. Additionally, even though the most of the topics and the tasks are suitable for personalization, the coursebooks mainly focus on a third person rather than the learners themselves. Indeed, the coursebooks fail to make use of what students bring to the classroom. Hence, there is no sufficient personalization in the coursebooks. Besides, the learners are not required to think critically, creatively or analytically in most of the activities. Treating the learners as a cultural informant, privileging the cultural knowledge that they bring to the classroom, and using it to help them share their own individual perspectives with the teacher as well as other learners whose lives, and hence perspectives, differ from theirs are mostly likely to learn to long-term acquisition (Kumaravadivelu, 2003).

Nor do the coursebooks encourage learners to continue learning English by themselves and thus lack the encouragement for autonomy. The activities are designed to practice language items within the classroom environments. Hence, learning does not go beyond the classroom environment. In fact, the units provide very limited tasks to encourage learners to use or learn English outside of the course itself. Nor do the coursebooks guide or encourage learners to make discoveries by themselves. The coursebooks contain only dialogues as text materials and do not expose learners to extensive authentic use of English. The supplementary resources for self-study were also found to be insufficient in terms of enabling learners to use the language outside the classroom environment or after the course. The bombardment of repetitive practice activities that only assess accuracy does not seem to be able to lead to long-term acquisition of English. Furthermore, the way the second grade coursebook gives instructions for the tasks seems to be very direct and command like! Even though it seems to be a way to simplify the content for the learners who are most likely to be 8-10 years old, this might be inappropriate if the coursebooks aim to engage the learners affectively.

Indeed, the average scores of the coursebooks were indicated to be very low, and the coursebooks do not seem to be able to meet the requirements of the universal coursebook evaluation criteria. This deficiency of the Turkish public school English coursebooks has also been indicated by a group of scholars in Turkey (e.g., Çakıt, 2006; Tilfarlıŏlu \& Öztürk, 2007; Kayapınar, 2009; Dülger, 2016). For example, in Tilfarlıoglu and Öztürk's (2007) study, the majority of the English instructors asserted that the coursebooks are not well-developed, and this has resulted in overreliance of the Turkish language teachers over grammar and reading as the contents of the coursebooks are mainly dominated by the readings texts and grammatical points. In a similar vein, Dülger (2016) and Çakıt's (2006) investigations indicated teachers and students' dissatisfaction with the public schools English language coursebooks in Turkey. In a nutshell, the strand of research conducted in Turkey on the effectiveness of the coursebooks used at public schools has indicated that both the teachers and students' perceptions on the coursebooks are not entirely satisfactory. In Çelik and Kasapoğlu's (2014) study on the beliefs of a group of elementary school administrators on teaching English to younger students, as well as their general opinions on English language education in Turkey, the administrators also expressed their concerns about the recently developed teaching program and indicated a general consensus that major revision was urgently needed.

In a project conducted in November 2013 run by the British Council and the Economy Policy Research Foundation of Turkey, Vale et al (2013) carried out needs assessment of Turkish public school English language teaching and thoroughly investigated the practice of teaching English in Turkish state schools. The inadequacy of the English coursebooks used in Turkish public schools has been also echoed in the report which identified five major restraints underlying the English deficit in Turkish public schools. Among them is the deficiency of the English at public schools coursebooks, asserting that the currently-used coursebooks and curricula are quite inappropriate for the needs and different proficiency 
levels of the learners. In their report, Vale et al. (2013) attributed this deficiency in learning English to defective teaching in primary and secondary schools, focusing on mediocre requirements of teaching at primary and secondary public schools.

\section{Conclusion}

The findings of the study can enlighten the possible measures to be taken by the Turkish Ministry of National Education to ameliorate the English coursebooks deficiency and consequently the English deficit of the Turkish students studying at public schools. Being the most usually utilized materials in the classroom and the commonly recognized elements for use in teaching-learning encounters in educational settings, the language coursebooks undoubtedly play a facilitating role in foreign language education. As English language proficiency in Turkey has been constantly ranked very low on globally recognized proficiency benchmarks over the last decades, immediate and constructive steps need to be taken to modify the English coursebooks used in English language education at state schools so as to pave the way for the effective instruction of English in Turkish schools.

It is worth noting that, as aforementioned, the nature of materials evaluation is inevitably subjective no matter how accurate, standardized, and criterion referenced an evaluation claims to be (Tomlinson, 2013). Even though the interpretations of the evaluated coursebook and the decisions on the effectiveness of the materials went thoroughly with the focus on Tomlinson and Masuhara's (2013) set of universal coursebook evaluation criteria, they are likely to differ if the evaluation is conducted by a different group of evaluators. In this study, only pre-use evaluation of the coursebook was conducted, the studies on whilst-use evaluation, and post-use evaluation of the present coursebooks would shed more light on their potential efficiency and their long term effectiveness in language learning. The perceptions of the Turkish public elementary school teachers and the students as a determining factor in deciding on the effectiveness of the contents of the coursebooks also appear to be fruitful avenues for future research.

\section{Ethics Committee Approval}

The author(s) confirm(s) that the study does not need ethics committee approval according to the research integrity rules in their country (Date of Confirmation: June 06, 2020).

\section{References}

Abdelwahab, M. M. (2013). Developing an English language textbook evaluative checklist. IOSR Journal of Research \& Method in Education, 1(3), 55-70.

Akkaya, S. (2019). An evaluation of 2nd graders' English course book "English 2" from teachers' perspective (Unpublished master dissertation). Institute of Social Sciences, Istanbul: Istanbul Sabahattin Zaim University.

Allwright, D. (1981). What do we want teaching materials for? ELT Journal, 1, 5-18.

Arıkan, G. (2008). Textbook evaluation in foreign language teaching: Time for English, grade 4: Teachers' and students' views (Unpublished master dissertation). Institute of Social Sciences, Adana: Cukurova University. 
Aytuğ, S. (2007). An EFL textbook evaluation study in Anatolian high schools: New bridge to success for 9th grade new beginners (Unpublished master dissertation). The Graduate School of Education, Ankara: Bilkent University.

Bahman, M., \& Rahimi, A. (2010). Gender representation in EFL materials: An analysis of English textbooks of Iranian high schools. Procedia Social and Behavioral Sciences, 9, 273-277.

Brown, J. B. (1997). Textbook evaluation form, The Language Teacher, 21(10), 15-21.

Byrd, P. (2001). Textbooks: Evaluation for selection and analysis for implementation. In Celce-Murcia, M. (Eds.), Teaching English as a second or foreign language (pp. 415-427). Heinle \& Heinle.

Chambers, F. (1997). Seeking consensus in coursebook evaluation. ELT Journal, 51(1), 30-35.

Crewe, J. (2011). How far do 'global' ELT coursebooks realize key principles of Communicative Language Teaching (CLT) and enable effective teaching-learning? (Unpublished master dissertation). The School of Humanities, Birmingham: University of Birmingham

Cunningsworth, A. (1995). Choosing your coursebook. Oxford: Macmillan Heineman.

Çakit, I. (2006). Evaluation of the the EFL textbook "New Bridge to Success 3" from the perspectives of students and teachers (Unpublished master dissertation). School of Social Sciences, Ankara: The Middle East Technical University.

Çelik, S., \& Kasapoğlu, H. (2014). Implementing the recent curricular changes to English language instruction in Turkey: Opinions and concerns of elementary school administrators. South African Journal of Education, 34(2), 1-14.

Davcheva, L., \& Sercu, L. (2005). Culture in Foreign Language Teaching Materials. In Sercu et al. (Eds.), Foreign Language Teachers and Intercultural Competence (pp. 90-109). Multilingual Matters LTD.

Dodgson, D. (2019). 6 reasons for using coursebooks (from a teacher who doesn't usually like them). . Retrieved on February 15, 2020 from https://www.modernenglishteacher.com/2019/6-reasons-forusing coursebooks-from-a-teacher-who-doesn-t-usually-like-them

Dubin, F., \& Olshtai, E. (1986). Course design: Developing programmes and materials for language learning. Cambridge: Cambridge University Press.

Dülger, O. (2016). Evaluation of EFL coursebooks taught in Turkey based on teachers' views. Journal of Advances in English Language Teaching, 4(1), 1-11.

Gearing, K. (1999). Helping less experienced teachers of English to evaluate teacher's guides, ELT Journal, 53(2), 122-127.

Gray, J. (2006). A Study of cultural content in the British ELT global coursebook: A cultural studies approach (Unpublished doctorate dissertation). Institute of Education. London: University of London.

Hutchinson, T., \& Torres, E. (1994). The textbook as agent of change. ELT Journal, 48(4), 315-327.

Haycroft, J. (1998). An introduction to English language teaching. The UK: Longman.

Kayapınar, U. (2009). Coursebook evaluation by English teachers. Inonu University Journal of the Faculty of Education, 10(1), 69-78. 
Kramsch, C. (1988). The cultural discourse of foreign language textbooks. In A. J. Singerman (Eds.), Toward a new integration of language and culture (pp. 63-88). Middlebury, VT: Northeast Conference on the Teaching of Foreign Languages.

Littlejohn, A. (1998). The analysis of language teaching materials: Inside the Trojan horse. In B. Tomlinson (eds.), Materials development in language teaching (pp. 190-216). Cambridge: Cambridge University Press.

McDonough, J., \& Shaw, C. (1993), Materials and methods in ELT: A teacher's guide. London: Blackwell.

McKay, S. L. (2003). Toward an appropriate EIL pedagogy: Re-examining common ELT assumptions. International Journal of Applied Linguistics, 13(1), 1-22.

Mukundan, J., \& Ahour, T. (2010). A review of textbook evaluation checklists across four decades (1970-2008). In B. Tomlinson and H. Masuhara (Eds.), Research for materials development in language learning: Evidence for best practice (pp. 336-52). London: Continuum.

Öz, Ö. (2019). A post-use evaluation of an EFL coursebook from the perspectives of preparatory school students and instructors: A mixed methods study (Unpublished master dissertation). The Graduate School of Social Sciences, Ankara: Middle East Technical University.

Özdemir, F. E. (2007). An evaluation of Time for English 4, the 4th grade English coursebook for public schools (Unpublished master dissertation). School of Social Sciences, Ankara: Middle East Technical University.

Sercu, L. (2005). The future of intercultural competence in foreign language education: Recommendations for professional development, educational policy and research. In Sercu et al. (Eds.), Foreign language teachers and intercultural competence (pp. 160-185). Clevedon: Multilingual Matters.

Sheldon, L. E. (1988). Evaluating ELT textbooks and materials. ELT Journal, 42(4), 237-246.

Skierso, A. (1991), Textbook selection and evaluation. In M. Celce-Murcia and L. McIntosh (Eds.), Teaching English as a second or foreign language (pp. 432-53). Boston: Heinle and Heinle.

Tilfarlıŏlu, F. Y. \& Öztürk, A. R. (2007). An Analysis of ELT teachers' perceptions of some problems concerning the implementation of English language teaching curricula in elementary schools. Journal of Language and Linguistic Studies, 3(1), 202-217.

Tomlinson, B. (1999). Developing criteria for materials evaluation, IATEFL Issues, 147, 10-13.

Tomlinson, B. (2013). Introduction: Are materials developing? In B. Tomlinson (Eds.), Developing materials for language teaching (pp. 1-17). Bloomsbury Publishing Plc.

Tomlinson, B., \& Masuhara, H. (2013). Adult coursebooks. ELT Journal, 67(2), 233-249.

Tsiplakides, I. (2011). Selecting an English coursebook: theory and practice. Theory and Practice in Language Studies, 1(7), 758-764.

Ur, P. (1996). A course in language teaching: Practice and theory. Cambridge: Cambridge University Press.

Vale, D., Özen. E. N., Alpaslan, I. B., Çağlı, A., Özdoğan, I., Sancak, M., Dizman, A. O., \& Sökmen, A. (2013). Turkey national needs assessment of state school English language teaching. Ankara: British Council. 


\title{
Türkiye'de devlet ilköğretim okullarında kullanılan İngilizce ders kitaplarının
}

\author{
değerlendirilmesi
}

\section{Öz}

Bu çalışmada, Türkiye'deki Devlet İlköğretim okullarında kullanılan İngilizce ders kitaplarının sistematik olarak değerlendirilmesi yapılmıştır. Çalışmada, TC Milli Eğitim Bakanlığı tarafından hazırlanan müfredatın İngilizce derslerinde kullanılan bir dizi ders kitabı,Tomlinson ve Masuhara'nın (2013) evrensel ders kitabı değerlendirme ölçütleri kullanılarak sistematik olarak değerlendirilmiştir. Sonuçlarda, ders kitaplarının; düzen, dinleme becerisi, kullanılan resimler ve duygusal katılımı sağlama gibi olumlu özelliklere sahip olduğu, fakat bu özelliklerin yanısıra birçok olumsuz özellikleri de barındırdığı görülmüştür. Değerlendirme sonuçlarında, Türkiye'de devlet ilköğretim okullarında işlenen İngilizce ders kitapları, iletişim temelli faaliyetler sunma, İngilizce'yi sınıf dışında kullanmaya teşvik etme, keşfi teşvik eden girdiler sağlama ve en önemlisi İngilizce'ye maruz bırakma gibi etkin dil edinimi için gerekli önemli koşulları sağlama yönünden yetersiz bulunmuştur. Ders kitaplarının odak noktasının, etkili sonuçlar, anlamlı iletişim ve uzun vadeli dil edinimi yerine, bilgi ölçme ve tekrar olduğu görülmüştür. Değerlendirilen ders kitaplarındaki etkinliklerin büyük bir bölümü, öğrencilerin üretkenliklerini göstermelerine ve özerklik kazanmalarına mahal vermeyen alıştırma etkinliklerinden oluşur. Ayrıca, yeterli kişiselleştirme yoktur ve ders kitapları öğrencilerin sınıfa getirebilecekleri tecrübeleri göz ardı etmiş̧tir. Buna ek olarak, etkinliklerin çoğu öğrencilerin eleştirel, yaratıcı veya analitik düşünme becerisini gerektirmemektedir. Ders kitapları, öğrencileri İngilizce öğrenimlerine kendi başlarına devam etmeye teşvik etmez, dolayısıyla özerklik kazanmaya cesaretlendirmekten yoksundur. Kitaptaki etkinlikler, dil öğelerini sınıf ortamında uygulamak için tasarlanmıştır. Dolayısıyla, öğrencileri kendi başlarına keşifler yapabilmeleri için yönlendirmediği veya teşvik etmediğinden ders kitabının sağlayacağı öğrenme sınıf ortamının ötesine geçemez. Öğrencileri, sadece bilgi ölçen alıştırma etkinliklerine maruz bırakmak, İngilizcenin uzun vadeli edinilimine imkan vermiyor.

Anahtar sözcükler: ders kitapları; ders kitaplarının değerlendirilmesi; devlet okulları; ders kitabı yetersizliği; İngilizce yetersizliği

\section{AUTHOR BIODATA}

Mehdi Solhi is an assistant professor in the Department of English Language Teaching at Istanbul Medipol University, Istanbul, Turkey. His research interests include Applied Linguistics, Teaching English as an International Language, Cultural Studies, Coursebook Evaluation, and Teaching Writing. His publications include articles in various refereed journals in the field.

Meryem Sak Masrı holds a bachelor's degree in English language teaching from Istanbul Medipol University. She double majors in Psychological Counseling and Guidance program at Istanbul Medipol University. Her research interests center on ELT Materials Evaluation, Culture and Language, teaching English as a Lingua Franca, Sociolinguistics, and Learner Autonomy.

Şeyda Şahin holds a bachelor's degree in English language teaching from Istanbul Medipol University. She double majors in Psychological Counseling and Guidance at Istanbul Medipol University. Her research interests include Gamification in Language Teaching, Material Development, Learner Psychology, and Neurobiology of Language Acquisition.

Hanife Selin Yılmaz holds a bachelor's degree in English language teaching from Istanbul Medipol University. Her research interests include Educational Technologies, Material Design and Development, and Teaching English as a Foreign Language. 